\title{
IMPLEMENTASI PERANAN PENDAMPING DESA DALAM PENGAWASAN PEMERINTAH DESA DI KECAMATAN MARIORIWAWO KABUPATEN SOPPENG
}

\author{
Faradillah Paratama, Herviani \\ Universitas Sawerigading, Faradillahparatama.92@gmail.com
}

\begin{abstract}
Abstrak
Pendamping desa merupakan seorang yang berkompeten yang ditugaskan untuk mendampingi Desa terhadap pembangunan dan pemberdayaan masyarakat desa. Tujuan penelitian ini yakni untuk mengetahui bentuk pelakasanaan peranan pendamping desa dalam mengawasi jalannya Pemerintah Desa sebagaimana aturan perundang-undangan. Penelitian ini menggunakan tipe penelitian hukum dengan pendekatan empiris, dimana data diperoleh langsung dari lapangan melalui wawancara dan pengamatan, data yang diperoleh dianalisis secara kualitatif kemudian dipaparkan secara deskriktif. Hasil penelitian menunjukkan bahwa implementasi peranan pendamping desa telah membawa perubahan dalam pembangunan dan pemberdayaan masayarakat desa di Kecamatan Marioriwawo utamanya dalam pemerataan pembangunan dan upaya peningkatan sumber daya manusia di Desa dan dijalankan tetap pada pedoman yang diatur dalam undang-undag desa berserta aturan pelaksana lainnya.

Kata Kunci: Pendamping Desa, Pemerintah Desa, Pemberdayaan Masyarakat.
\end{abstract}

\begin{abstract}
A village assistant is a competent person assigned to assist the village in the development and empowerment of village communities. The purpose of this study is to determine the form of implementation of the role of village assistants in supervising the operation of the village government as per the laws and regulations. This study uses a legal research type with an empirical approach, where data is obtained directly from the field through interviews and observations, the data obtained are analyzed qualitatively and then described descriptively. The results of the study indicate that the implementation of the role of village assistants has brought changes in the development and empowerment of village communities in Marioriwawo District, especially in equitable development and efforts to increase human resources in the village and are carried out according to the guidelines regulated in the village law along with other implementing regulations.

Keywords: Village Facilitator, Village Government, Community Empowerment.
\end{abstract}

\section{Pendahuluan}

Negara Indonesia yang lahir pada 17 Agustus 1945 adalah Negara Kesatuan yang berbentuk Republik. Dalam penyelenggaraan pemerintahannya, Daerah Indonesia terdiri atas beberapa daerah atau wilayah provinsi dan setiap daerah atau wilayah provinsi terdiri atas beberapa daerah kabupaten atau kota. Selanjutnya di dalam tiap daerah kabupaten atau kota terdapat satuan pemerintah terendah yang 
disebut Desa dan Kelurahan. Dengan demikian, desa dan kelurahan adalah satuan pemerintahan terendah di bawah pemerintah Kabupaten atau Kota. ${ }^{1}$

Dalam perjalanan ketatanegaraan Republik Indonesia, desa telah berkembang dalam berbagai bentuk, sehingga perlu dilindungi dan diberdayakan agar menjadi kuat, maju, mandiri, dan demokratis sehingga dapat menciptakan landasan yang kuat dalam melaksanakan pemerintahan dan pembangunan menurut masyarakat yang adil, makmur dan sejahtera. ${ }^{2}$ Oleh karena itu keadilan menjadi syarat bagi terciptanya kebahagiaan hidup untuk negaranya, dan sebagai dasar dari pada keadilan itu perlu diajarkan rasa susila kepada setiap manusia agar ia menjadi warga Negara yang baik, demikian pula peraturan hukum yang sebenarnya hanya ada jika peraturan hukum itu mencerminkan bagi pergaulan hidup antar warga negarannya. ${ }^{3}$

Desa adalah kesatuan masyarakat yang memiliki batas wilayah yang berwenang untuk mengatur dan mengurus urusan pemerintahan, pembangunan desa, kepentingan masyarakat setempat berdasarkan prakarsa masyarakat, hak asal usul dan/atau hal tradisional yang diakui dan dihormati dalam sistem pemerintahan negara Indonesia. ${ }^{4}$

Meskipun mendapat julukan sebagai pucuk pemerintahan di wilayah kesatuan Republik Indonesia, peranan Pemerintah Desa tak dapat dikesampingkan. Sebagai Lembaga Pemerintahan, Desa merupakan ujung tombak pemberian layanan kepada masyarakat. Sedangkan sebagai entitas kesatuan masyarakat hukum, Desa merupakan basis sistem kemasyarakatan bangsa Indonesia yang sangat kokoh sehingga dapat menjadi landasan yang kuat bagi pengembangan sistem politik, ekonomi, sosial-budaya, dan hankam yang stabil dan dinamis.

Landasan pemikiran dalam mengenai Pemerintahan Desa adalah keanekaragaman, partisipasi, otonomi asli, demokratisasi dan pemberdayaan masyarakat. ${ }^{5}$ Oleh sebab itu, kedudukan Desa dalam kelembagaan pemerintahan berperan penting dan mempunyai posisi yang strategis.

Ditinjau dari fungsi Pemerintahan, baik Pemerintah Pusat, Daerah, maupun Desa, fungsi Pemerintahan adalah memberikan pelayanan kepada masyarakat. Pelayanan tersebut terdiri atas pelayanan publik, pelayanan pembangunan, dan pelayanan perlindungan. Pemberian layanan tersebut ditujukan untuk menciptakan kesejahteraan masyarakat. Namun faktanya hal tersebut tidak berlaku bagi Desa.

\footnotetext{
${ }^{1}$ Hanif Nurcholis, 2011, Pertumbuhan Dan Penyelenggaraan Pemerintah Desa. Erlangga, Jakarta, 2011 , hlm. 1

2 Moch. Solekhan, 2014, Penyelenggaraan Pemerintah Desa Berbasis Partisipasi Masyarakat, Setara Press, Malang, hlm. 13

${ }^{3}$ Moh. Kusnardi Dkk, 1998, Hukum Tata Negara Indonesia, Sinar Bakti, Jakarta, hlm. 153

${ }^{4}$ Bintaro, 1989, Interaksi Desa-Kota Dan Menurut Permasalahannya. Ghalis Indonesia, Jakarta, hlm. 13

${ }^{5}$ HAW. Widjaja, 2003, Otonomi Desa Merupakan Otonomi yang Asli Bulat dan Utuh, PT Raja Granfindo Persada, Jakarta, hlm.3
} 
Dimana jika kita berbicara tentang keterbelakangan bangsa Indonesia, maka alamat utamanya adalah desa-desa beserta masyarakatnya. Hal tersebut dapat dimaklumi karena sebagian besar warga masyarakat Indonesia berdomisili di wilayah pedesaan. ${ }^{6}$

Maka guna menghilangkan citra buruk yang melekat pada Desa, pelayanan pembangunan merupakan suatu cara yang dilakukan oleh Pemerintah Desa dalam bentuk melakukan pembangunan yang berdampak kepada peningkatan pendapatan warga desa baik langsung maupun tidak langsung. Pembangunan merupakan suatu cara dalam upaya pengembangan wilayah pedesaan yang kemudian dapat menjadikan Desa yang mandiri yang dapat mengelola sumber kekayaan Desa dengan baik. Dengan pembangunan Desa akses pengelolaan kekayaan Desa berjalan dengan lancar sehingga dapat dinikmati oleh masyarakat Desa. ${ }^{7}$

Pelaksanaan pembangunan masa lalu menempatkan pemerintah seolah-olah sebagai agen tunggal pembangunan, sedang masyarakat desa dianggap tidak memiliki kemampuan dan masih tertinggal. ${ }^{8}$ Namun paradigma itu mulai berubah sejak semangat pembangunan negara kita mulai melibatkan partisipasi rakyat, dimana dalam pembangunan Desa, hal tersebut telah di akomodir oleh UU Desa dengan menghadirkan masyarakat dalam pengawan jalannya pembangunan di Desa. Selain itu, guna mengarahkan Pemerintah Desa dalam melakukan pembangunan yang berkesesuaian dengan program nasional maka dianggap perlu adanya pendamping desa yang akan membantu mengingat luasnya cakupan tugas Pemerintah Desa.

Dalam Undang-Undang Nomor 6 Tahun 2014 Tentang Desa dan Peraturan Menteri Desa Nomor 3 Tahun 2015 tentang pendamping Desa memberikan keistimewaan bagi masyarakat dan bertambah dengan adanya kebijakan pemerintah yang berkaitan dengan pendamping Desa dibagian perangkat Desa. Keberadaan pendamping Desa ini harus bergerak cepat dalam membangun strategi dalam menuntaskan kemiskinan dan mengurangi kesenjangan sosial, tentunya sasaran adalah pembangunan fisik dan sarana prasarana Desa dengan tujuan membuka seluas-luasnya terhadap pembangunan Desa. Keberadaan pendamping Desa, dibentuk guna menyelenggarakan urusan pemerintah dan kepentingan masyarakat Desa setempat.

Peraturan Menteri Desa, Pembangunan Daerah Tertinggal, Dan Transmigrasi Republik Indonesia Nomor 3 Tahun 2015 sebagaimana diatur dalam Pasal 12,

\footnotetext{
${ }^{6}$ Raharjo, 2004, Pembangunan Desa: Mengapa Selalu Sisip Dari Harapan?, Jurnal Dinamika Pedesaan dan Kawasan, Volume 4, Nomor 4, hlm. 3-11.

7 Ibid. HIm. 104

${ }^{8}$ Wastutiningsih, Sri Peni. 2004. Pemberdayaan Petani dan Kemandirian Desa, Jurnal Dinamika Pedesaan dan Kawasan, Volume 4, Nomor 4, hlm. 12-18.
} 
Pendamping Desa melaksanakan tugas dalam mendampingi Desa. Terbentuknya pendamping Desa merupakan upaya dari perwujudan demokrasi ditingkat Desa. Pendamping Desa di tempatkan di desa agar dapat menggali, menampung dan menyalurkan aspirasi masyarakat dalam pembangunan kawasan pedesaan secara partisipatif serta peningkatan kapasitas bagi Pemerintah Desa. Tujuan dasar dari setiap program pembangunan adalah untuk meningkatkan kesejahteraan masyarakat. Jika pembangunan dapat dilakukan melalui metode pemberdayaan maka kesejahteraan diharapkan dapat tercapai. ${ }^{9}$ Harapan inilah yang dibebankan dipundak pendamping desa, selain keahlian dan pengaplikasian metodenya juga diharapkan dapat sejalan dengan aspirasi dan kebutuhan masyarakat yang telah digali dan ditampung oleh pendamping Desa dalam bekerjasama dengan Pemerintah Desa dalam menjalankan pembangunan seperti halnya pada beberapa desa di Kecamatan Marioriwawo, Kabupaten Soppeng.

Masyarakat di beberapa Desa di Kecamatan Marioriwawo tentunya menunggu program pembangunan dan pemberdayaan masyarakat setelah adanya pendamping desa di setiap desa. Namun kenyataannya belum ada gebrakan ataupun langkah strategis dan kebijakan yang mengarah pada perubahan guna meningkatkan pembangunan dan pemberdayaan masyarakat setelah adanya pendamping desa di daerah tersebut. Oleh sebab itu perlu adanya kajian empiris terkait peranan pendamping desa dalam rangka pembangunan dan pemberdayaan masyarakat desa yang dianggap masih kurang maksimal dalam menjalankan peranannnya.

Sebagaimana latar belakang tersebut, maka dari itu menarik untuk mengkaji bagaimanakah wujud pelakasanaan pendamping Desa sebagaimana yang diatur dalam Undang-Undang Nomor 6 Tahun 2014 dalam mengawasi jalannya pemerintah desa utamanya dalam pembangunan dan pemberdayaan masyarakat desa.

\section{Metode}

Penulisan artikel ini menggunakan jenis penelitian empiris dengan melihat fakta empirik di lapangan. Penelitian dilakukan di Kecamatan Marioriwawo Kabupaten Soppeng. Data yang digunakan adalah data primer dengan melakukan observasi dan wawancara terhadap pendamping desa. Data yang diperoleh kemudian dianalisis secara kuantitatif.

\section{Peran dan Tugas Pendamping Desa}

Pemberdayaan masyarakat desa ditujukan untuk meretas kemiskinan, meningkatkan kemandirian serta meningkatkan kesejahteraan masyarakat desa.

\footnotetext{
${ }^{9}$ Muslim, A., 2012. Dasar-dasar Pengembangan Masyarakat. Samudra Biru Press, Yogyakarta
} 
Melalui pendampingan yang dilakukan diyakini mampu mendorong kemampuan dan kreatifitas masyarakat desa untuk dapat hidup mandiri. Dengan demikian, pemberdayaan senantiasa dapat menyentuh dua aspek, yaitu adanya pembukaan ruang gerak yang bebas bagi masyarakat menjadi lebih mamu dalam mengaktualisasikan diri untuk menciptakan masyarakat desa yang mandiri. ${ }^{10}$

Tenaga Pendamping Desa ialah sebuah jabatan dibawah naungan kementerian Desa, Pembangunan Daerah Tertinggal Dan Transmigrasi Indonesia, yang ditugaskan untuk mendampingi pemerintah dalam pemberdayaan masyarakat Desa dalam rangka mengimplementasikan Undang-Undang No 6 tahun 2014 tentang Desa. Menurut Madhafie, tugas dari Pendamping Desa yaitu sebagai fasilitator dan pendamping pemerintah desa dan masyarakat desa dalam penyelenggaraan pemerintahan desa, pelaksanaan pembangunan desa, membina dan memberdayakan masyarakat desa. ${ }^{11}$

Pendamping Desa adalah tenaga pembantu, yaitu untuk membantu pemerintah dalam melaksanakan tugasnya dalam pembangunan Desa. Penyelenggaraan pemberdayaan dan pendampingan terhadap masyarakat sejatinya adalah tugas pemerintah sesuai dengan ketentuan Undang-Undang yakni Pemerintah dan Pemerintah daerah melakukan pemberdayaan masyarakat Desa dengan pendampingan secara berjenjang sesuai dengan kebutuhan, yang secara teknis dilaksanakan oleh satuan Kerja Prangkat Daerah Kabupaten/atau Kota, dapat dibantu oleh tenaga pendamping professional atau yang disebut dengan pendamping Desa.

Dalam Peraturan Kementerian Desa ditegaskan bahwa terdapat tujuh tugas pokok pendamping desa, yaitu :12

a. Mendampingi desa dalam perencanaan, pelaksanaan dan pemantauan terhadap pembangunan desa dan pemberdayaan masyarakat desa.

b. Mendampingi desa dalam melaksanakan pengelolaan pelayanan sosial dasar, pengembangan usaha ekonomi desa, pendayagunaan sumber daya alam dan teknologi tepat guna, pembangunan sarana prasarana desa, dan pemberdayaan masyarakat desa.

c. Melakukan peningkatan kapasitas bagi Pemerintahan Desa, lembaga kemasyarakatan desa dalam hal pembangunan dan pemberdayaan masyarakat desa.

d. Melakukan pengorganisasian di dalam kelompok masyarakat desa.

e. Melakukan peningkatan kapasitas bagi kader pemberdayaan masyarakat desa dan mendorong terciptanya kader pembangunan desa yang baru.

\footnotetext{
10 M. Saleh Laha, Ronaldi Dorohungi, 2021, Peran Pendamping Desa Dalam Pemberdayaan Masyarakat Di Distrik Numfor Barat Kabupaten Biak Numfor, Jurnal Governance and Politics, Volume 1, Nomor 1, hlm. 30

11 Deni Triyanto, 2018, Analisis Kinerja Pendamping Desa Dalam Upaya Membangun Kemandirian Desa, Jurnal Penelitian Sosial dan Politik, Volume 7 Nomor 2, hlm. 57

12 M. Saleh Laha, Ronaldi Dorohungi, Op.cit, hlm. 31
} 
f. Mendampingi desa dalam pembangunan kawasan perdesaan secara partisipatif. g. Melakukan koordinasi pendampingan di tingkat kecamatan dan memfasilitasi laporan pelaksanaan pendampingan oleh Camat kepada Pemerintah Daerah Kabupaten/Kota.

Untuk dapat melaksanakan tugas pendampingan secara maksimal, maka diperlukan tenaga pendamping desa yang memenuhi kualifikasi. Kualifikasi tenaga pendamping pemberdayaan masyarakat desa memiliki acuan baku yang dirumuskan oleh Tim Persiapan Lembaga Sertifikasi Profesi Fasilitator Pemberdayaan Masyarakat yang difasilitasi oleh Kementerian Dalam Negeri bersama-sama dengan British Council.13 Adapun kualifikasi yang dimaksud digolongkan kepada tiga kompetensi, yakni kompetensi umum, kompetensi inti dan kompetensi khusus. dari : $: 14$

Kompetensi umum yang dibutuhkan untuk menjadi pendamping desa terdiri

a. Membangun relasi sosial

b. Mengoptimalkan pemanfaatan sumber daya masyarakat.

c. Menyadarkan kebutuhan masyarakat.

d. Melaksanakan fasilitasi pembelajaran.

e. Meningkatkan aksesibilitas antar pemangku kepentingan.

f. Membangun visi dan kepemimpinan.

Kompetensi inti bagi pendamping desa yaitu : ${ }^{15}$

a. Membangun jejaring dan kemitraan.

b. Membangun modal sosial

c. Membangun kapasitas kelembagaan masyarakat dan pemerintahan.

d. Memperkuat posisi tawar.

e. Merancang perubahan.

f. Mendesain proses pembelajaran.

g. Menyiapkan kader pemberdayaan masyarakat.

h. Mengembangkan kemandirian masyarakat.

i. Meningkatkan aksesibilitas antar pemangku kepentingan.

j. Mengelola konflik.

k. Mengembangkan sistem sanksi reward and punishment.

Sedangkan kompetensi khusus yang harus dimiliki oleh seorang tenaga pendamping pemberdayaan masyarakat desa adalah

a. Mengembangkan ide, metoda, produk baru di bidang/ sektor kegiatan tertentu.

b. Memfasilitasi penerapan ide, metoda, produk baru di bidang/sektor kegiatan tertentu.

\section{Implementasi Tugas Pendamping Desa Berdasarkan Undang-Undang di Kecamatan Marioriwawo Kabupaten Soppeng}

\footnotetext{
13 Icol Dianto, 2018, Problematika Pendamping Desa Profesional dalam Pemberdayaan Masyarakat Desa di Kota Padangsidimpuan, Dimas, Volume 18 Nomor 2, hlm. 244.

${ }^{14}$ Ibid

15 Ibid, hlm 245
} 
Pendamping desa dibentuk atas inisiatif Kementerian Desa, Pembangunan Daerah Tertinggal dan Transmigrasi pada program pembangunan dan pemberdayaan masyarakat Desa. Adapun tugas yang diberikan pemerintah kepada pendamping desa yaitu berupa melakukan pendampingan dan pengawasan, artinya bahwa tugas pendamping Desa hanya membantu mengarahkan dengan cara memberikan saran, ide-ide, dan gagasan-gagasan serta membimbing dan meningkatkan kesejahteraan masyarakat agar masyarakat lebih partisipan dalam pelaksanaan pembangunan Desanya.

Pendamping desa saat ini telah ada dan ditempatkan pada tiap-tiap Desa di Indonesia, seperti halnya pada Desa Watu, Desa Watu Toa, Desa Marioriaja di Kecamatan Marioriwawo, Kabupaten Soppeng. Para pendamping desa pada beberapa Desa tersebut memiliki tugas dan fungsi sebagaimana yang diatur dalam UU Desa dan beberapa peraturan pelaksana lainnya yang pada pokoknya berperan dan bertugas mengawal jalannya program pemerintah Desa Watu, Desa Watu Toa dan Desa Marioriaja.

Seperti halnya yang disampaikan oleh Bapak Juhari, S.E., MM selaku Kepala Desa Watu, mengatakan bahwa "Pendamping Desa yang dibentuk oleh pemerintah hanya sebagai fasilitator yaitu mendampingi dan menfasilitasi pemerintah Desa untuk membantu pemerintah Desa dalam rangka memenuhi kebutuhan masyarakat dalam mengelola dan memperdayakan sumber daya yang ada di Desa tersebut. ${ }^{16}$

Pernyataan tersebut telah menegaskan bahwa pendamping desa pada desa tersebut telah mengambil peranan dalam penyelenggaraan pemerintahan desa di Desa Watu. Para pendamping desa diharapkan dapat mengimplementasikan kebijakan pemerintah dalam rangka kesejahteraan masyarakat Desa dalam upaya melakukan pembangunan di Desa guna menciptakan kehidupan bernegara yang adil dan Makmur dengan terjaminnya kesejahteraan rakyat dalam bentuk masyarakat Desa yang mandiri.

Fakta empirik menunjukkan bahwa terjadinya kesenjangan antara Kota dan Desa merupakan salah satu faktor pendorong ditetapkannya kebijakan dalam pembangunan desa dan pemberdayaan masyarakat yang terangkum pada beberapa regulasi yang ada di Negara Republik Indonesia. Kebijakan tersebut kemudian dapat diwujudkan jika didukung dengan SDM yang berkompeten untuk mencapai tujuan dari regulasi tersebut, maka dari itu disinalah peranan pendamping Desa sebagai sebuah motor penggerak di Desa guna mendorong sumber daya dan kesejahteraan di tingkat Desa.

Sesuai dengan Peraturan Pemerintah Republik Indonesia No. 47 Tahun 2015 perubahan atas Peraturan Menteri No.43 Tahun 2014 tentang pelaksanaan UndangUndang Nomor 6 Tahun 2014 tentang Desa telah dijelaskan bahwa pendamping

${ }^{16}$ Wawancara dengan Kepala Desa Watu, pada Tanggal 2 Juli 2021. 
Desa yaitu terdiri dari tiga Pendamping Lokal Desa (PLD) yang berkedudukan di desa, tenaga Pendamping Desa yang bertugas di Kecematan, Tenaga Ahli yang bertugas ditingkat Kabupaten. Dimana pendamping Desa melaksanakan tugas mendampingi Desa meliputi:

a. Pendamping Desa Mendampingi Desa dalam perencanaan pembangunan dan pemberdayaan masyarakat.

b. Pendamping Desa Mendampingi Desa dalam pelaksanaan pembangunan dan pemberdayaan masyarakat.

c. Pendamping Desa dalam pengawasan pelaksanaan pembangunan dan pemerdayaan masyarakat.

Berdasarkan wawancara yang dilakukan dengan Ibu Hartati selaku Pendamping (PLD) Desa Watu tugas yang beliau lakukan adalah "Mendampingi Desa dalam perencanaan, pelaksaanan, dan pemantauan terhadap pembangunan desa dan pemberdayaan masyarakat desa, saya selalu ikut serta dalam rencana pembangunan Desa baik dalam bidang Teknik maupun dalam bidang pemberdayaan masyarakat."17

Hal sama disampaikan oleh Ibu Andi Dita selaku Pendamping (PLD) Desa Watu Toa, beliau mengatakan bahwa "Tugas saya sebagai pendamping lokal Desa Watu Toa yaitu apapun yang dilakukan oleh Desa saya selalu ikut serta baik dalam rapat tentang Desa maupun untuk menerapkan hasil rapat tersebut kemudian saya laporkan yang menjadi kendala ke pendamping Desa kecematan."18

Senada dengan Ibu Sri Wahyuni selaku Pendamping Lokal Desa (PLD) Marioriaja, menyatakan bahwa "Tugas sebagai Pendamping Lokal Desa Marioriaja adalah seperti tugas pada umumnya pendamping Desa yang mengikuti dan menghadiri apapun rencana dari desa marioriaja dalam mensejahterahkan warganya."19

Keterangan yang didapatkan dari ketiga Pendamping Lokal Desa dapat disimpulkan bahwa apapun yang mereka lakukan selalu berpatokan dengan Undang-Undang Desa maupun Peraturan Menteri Nomor 3 Tahun 2015 Tentang Pendamping Desa. Menurut Ibu Sumiati selaku Pendamping Desa Kecematan Marioriwawo Kecematan Soppeng, "untuk memaksimalkan kerja pendamping Desa perlu diadakan pelatihan pendamping desa agar pekerjaan Pendamping Lokal Desa lebih baik yang sesuai dengan harapan pemerintah, karena pekerjaan pendamping lokal Desa saat ini belum terlalu jelas hanya menjalankan yang ada di Undang-Undang saja sementara masalah di Desa sangat Beragam." 20

Sesuai dengan peran dari pendamping Desa itu sendiri yaitu mengawal pembangunan desa dimulai tahap perencanaan, pelaksanaan dan pengawasan, untuk menjalankan itu semua harus diduking oleh sumber daya manusia yang

\footnotetext{
${ }^{17}$ Hartati, Pendamping Lokal Desa Watu, Wawancara, 2 Juli 2020

${ }^{18}$ Andi Dita, Pendamping Lokal Desa Watu Toa, 3 Juli 2020

${ }^{19}$ Sri Wahyuni. Pendamping Lokal Desa Marioriaja, Wawancara, 4 Juli 2020

${ }^{20}$ Sumiati, Pendamping Desa Kecematan, Wawancara, 2 Juli 2020
} 
berkulitas baik dari aparat pemerintah Desa Watu, Watu Toa dan Desa Marioriaja maupun masyarakatnya sendiri. Karena sesungguhnya pendamping Desa sifatnya hanya mendampigi dan membantu serta bersifat sementara sedangkan pemerintah Desa merupakan kepanjangan tangan dari pemerintah pusat yang bertanggung jawab untuk mengatur dan mengelola urusan-urusan pemerintahan dalam lingkup Desa secara demokratis sebagai konsekuensi dari pripsip desentralisasi pemerintahan.

Sebagaimana Pemerintahan Desa merupakan bagian dari pemerintahan nasional yang penyelenggaraannya ditujukan pada pedesaan. Pemerintahan Desa adalah suatu proses dimana usaha-usaha masyarakat desa yang bersangkutan dipadukan dengan usaha-usaha pemerintah untuk meningkatkan taraf kehidupan masyarakat. Lebih lanjut Pemerintahan Desa berdasarkan Peraturan Pemerintah Nomor 47 Tahun 2015 adalah penyelenggaraan urusan pemerintahan dan kepentingan masyarakat setempat dalam sistem pemerintahan Negara Kesatuan Republik Indonesia. ${ }^{21}$ Maka dari itu dengan ditempatkannya pendamping desa di Desa diharapkan dapat bersinergi dan membatu pemerintah desa dalam upayanya membangun desa guna meningkatkan taraf kehidupan masyarakat desa.

Maka dari itu sebagaimana yang kami amati, dalam melakukan perencanaan pembagunan Pendamping Desa bersama aparatur pemerintahan Desa Watu dan Watu Toa melaksanakan Rencana pembagunan Desa MUSDES dan lainnya Bersama-sama dengan Masyarakat Desa Watu Toa sehingga masyarakat bisa menyampaikan aspirasinya tentang masalah kebutuhan-kebutuhan dan harapanharapan secara langsung dalam rapat tersebut. Dengan cara-cara demikian maka pemerintah desa mengetahui dengan jelas sesungguhnya apa yang benar-benar dibutuhkan dan diharapkan oleh masyarakat.

Di Desa Marioriaja Kecematan Marioriwawo Kabupaten Soppeng, proses perencanaan pembagunan dilaksanakan dengan musyawarah bersama masyarakat Marioriaja untuk menentukan program-program pembangunan yang akan dilaksanakan.

Pembangunan dan pemberdayaan di Desa Watu, Watu Toa dan Desa Marioriaja diketahui dan dirasakan oleh warga masyarakat di Desa Watu, Watu Toa dan Desa Marioriaja, memang yang terlihat banyak pada pembangunan fisik infrastruktur, karena pembangunan fisik yang lebih nampak dalam penglihatan warga. "Adapun pembangunan yang pendamping Desa bantu selama periode kepala Desa di Desa Watu adalah renovasi kantor Desa, renovasi posyandu,renovasi taman kanak kanak,perbaikan jalan dan irigasi air."22 tutur Kepala Desa Watu Bapak Juhari. Lanjut Kepala Desa Marioriaja Bapak Hasminullah menuturkan Bahwa" Pembangunan yang

\footnotetext{
${ }^{21}$ Maria Eni Surasrih, 2006, Pemerintah Desa dan Implementasinya, Erlangga, Jakarta, hlm. 23

22 Juhari., Kepala Desa Watu. Wawancara 2 Juli 2020
} 
pendamping Desa bantu dalam pembangunan Desa yaitu renovasi kantor desa,TK,dan jalan menuju ke pemakaman serta perbaikan jalan akibat longsor. ${ }^{23}$ Begitupun dengan Desa Watu Toa yang dikepalai oleh Kepala Desa Hj. Andi Nilma mengatakan “ sejauh ini pendamping Desa sudah banyak membantu dalam pembangunan Desa diantaranya renovasi kantor desa,perbaikan irigasi air dan perbaikan jalan serta perbaikan lapangan. ${ }^{24}$

Keberadaan pendamping desa pada pelakasanaannya telah membawa sebuah semangat dalam pembangunan desa. Hal tersebut dapat dilihat dari respon positif masyarakat Desa Watu, Desa Watu Toa, Desa Marioriaja. Mereka membuka diri dengan senang hati bekerja sama dengan Pendamping desa dengan melaksanakan pembangunan desa demi mewujudkan Desa yang berkemajuan untuk mewujudkan ketentraman dan kesejahteraan di Desa Watu, Desa Watu Toa dan Desa Marioriaja. Ibu Andi Dita menyampaikan "Untuk masyarakat sendiri bisa saya katakan cukup menerima dengan baiklah, terlihat dari keaktifan mereka, semangat mereka untuk mnencari perubahan yang lebih baik". ${ }^{25}$

Langkah dan peranan yang ditunjukkan oleh PLD dalam menyerap asprasi dan turut mengajak masyarakat untuk turut terlibat dalam setiap tahapan jalannya pembangunan merupakan langkah yang efektif dalam mempercepat pembangunan desa. Tujuan umum dari partisipasi komunitas masyarakat desa adalah untuk menciptakan proses aktif dalam kelompok warga desa tersebutyang dapat mempengaruhi pelaksanaan pembangunan, daripada hanya sekadar menerima bagian dari manfaat suatu kegiatan. Oleh karena itu, partisipasi masyarakat merupakan proses aktif termasuk pemberdayaan, pembangunan kapasitas penerima, peningkatan efektivitas, peningkatan efisiensi, dan penghematan biaya dari suatu program atau kegiatan. ${ }^{26}$

Bapak Hasminullah menuturkan "kami bersyukurlah dan merasa sangat senang sekalilah dengan adanya pendamping desa ini kami merasa sangat terbantu dan kami sangat senang bahwa pemerintah memperhatikan kami melalui pengadaan pendamping desa yang membantu dalam pembangunan di Desa kami." 27 Sedangkan Bapak Alif Paturusi menuturkan " Adanya Pendamping Lokal Desa saya sebagai masyarakat Desa Watu sangat terbantu oleh kehadiran Pendamping Desa karena kita masyarakat biasanya tidak selalu hadir dalam hal-hal yang dilakukan oleh pemerintah Desa." 28

Lanjut dengan Ibu Suriani mengatakan bahwa " adanya pendamping lokal Desa sangat baik dibandingkan yang dulu seakan pemerintah desa bermasa bodoh untuk

\footnotetext{
${ }^{23}$ Hasminullah., Kepala Desa Marioriaja, Wawancara 4 Juli 2020

${ }^{24} \mathrm{Hj}$. Andi Nirma., Kepala Desa Watu Toa, 3 Juli 2020

${ }^{25}$ Andi Dita, Pendamping Lokal Desa Watu Toa, 3 Juli 2020

${ }^{26}$ Suroto, A, Heripracoyo, S, dan Irwansyah, E., 2020. Community Participation in Development of Spatial and Tabular Villages Database in Indonesia (Case Study: Poncol Pekalongan, Central Java). International Conference on Information Management and Technology (ICIMTech), IEEE, Bandung.

${ }^{27}$ Hasminullah., Kepala Desa Marioriaja, Wawancara 4 Juli 2020

${ }^{28}$ Alif Paturusi, Masyarakat Desa Watu, Wawancara, 2 Juli 2020
} 
memeperhatikan kesejahteraan warganya, tapi sekarang dengan adanya pendamping Lokal Desa mereka mulai melakukan perbaikan pembangunan bisa diliahta dari beberapa tempat sudah direnovasi." 29

Capaian yang dilakukan oleh para pendamping desa tentunya tidak dapat dilihat dan dinilai dalam kurung waktu singkat, namun setidaknya keberadaan pendamping desa telah memberikan patron bagi pemernitah desa dalam memeratakan pembangunan dan memberdayakan masyarakat desa. Mengingat bahwa kemajuan desa dan program pemberdayan masyarakat merupakan sebuah proses panjang yang dilakukan secara berjenjang dan berkelanjutan, sehingga tidak mungkin dicapai dalam waktu yang relatif singkat dan cepat.

Melihat fakta empirik dan keterangan yang telah kami peroleh, maka keberadaan pendamping desa telah membuat sebuah perubahan dan membawa tatanan penyelenggaraan pemerintah desa ke arah yang lebih baik. Jika di tingkat Pemerintah Daerah terdapat tim ahli maka ibarat di desa itu adalah pendamping desa. Tentunya pendamping desa telah membantu aparat pemerintah desa dalam melaksanakan pembangunan sumber daya dan pembangunan di Desa. Selain itu, pendamping desa juga berperan bersama dengan masyarakat desa mengawasi jalannya pemerintah desa agar tercipta pemerataan pembangunan yang berdampak pada semakin baiknya kesejahteraan masyarakat desa.

\section{Kesimpulan}

Pelakasanaan tugas pendamping desa telah dijalankan berdasarkan UndangUndang Nomor 6 Tahun 2014 tentang Desa serta Peraturan Menteri Desa Pembangunan Dearah Tertinggal dan Transmigrasi Nomor 3 Tahun 2015 tentang Pendampingan Desa, melalui peran Pendamping Desa di Desa Watu Watu Toa dan Desa Marioriaja Kecamatan Marioriwawo Kabupaten Soppeng telah terealisasi yaitu, dalam bentuk pendampingan pembangunan infrastruktur yang ada di Desa dan juga pemberdayaan masyarakat Desa. Keberadaan pendamping desa semakin menguatkan semangat otonomi desa yang tidak hanya digaunkan tetapi telah dihidupkan oleh pendamping desa guna menciptakan desa yang mandiri dan sejahtera.

\section{Referensi}

Bintaro.1989. Interaksi Desa-Kota Dan Menurut Permasalahannya. Ghalis Indonesia, Jakarta.

Deni Triyanto, 2018, Analisis Kinerja Pendamping Desa Dalam Upaya Membangun Kemandirian Desa, Jurnal Penelitian Sosial dan Politik, Volume 7 Nomor 2.

\footnotetext{
${ }^{29}$ Suriani, Masyarakat Desa Marioriaja, 4 Juli 2020
} 
Hanif Nurcholis. 2011. Pertumbuhan Dan Penyelenggaraan Pemerintah Desa, Erlangga, Jakarta.

HAW. Widjaja. 2003. Otonomi Desa Merupakan Otonomi yang Asli Bulat dan Utuh . PT Raja Granfindo Persada, Jakarta.

Icol Dianto, 2018, Problematika Pendamping Desa Profesional dalam Pemberdayaan Masyarakat Desa di Kota Padangsidimpuan, Dimas, Volume 18 Nomor 2.

M. Saleh Laha, Ronaldi Dorohungi, 2021, Peran Pendamping Desa Dalam Pemberdayaan Masyarakat Di Distrik Numfor Barat Kabupaten Biak Numfor, Jurnal Governance and Politics, Volume 1, Nomor 1.

Maria Eni Surasrih. 2006. Pemerintah Desa dan Implementasinya. Erlangga, Jakarta.

Moch. Solekhan.2014. Penyelenggaraan Pemerintah Desa Berbasis Partisipasi Masyarakat, Setara Press, Malang

Moh. Kusnardi Dkk.1998. Hukum Tata Negara Indonesia. Jakarta: Sinar Bakti.

Muslim, A., 2012. Dasar-dasar Pengembangan Masyarakat. Samudra Biru Press, Yogyakarta

Raharjo. 2004. Pembangunan Desa: Mengapa Selalu Sisip Dari Harapan, Jurnal Dinamika Pedesaan dan Kawasan, Volume 4, Nomor 4.

Suroto, A., Heripracoyo, S., dan Irwansyah, E., 2020. Community Participation in Development of Spatial and Tabular Villages Database in Indonesia (Case Study: Poncol Pekalongan, Central Java). 2020 International Conference on Information Management and Technology (ICIMTech), IEEE, Bandung.

Wastutiningsih, Sri Peni. 2004. Pemberdayaan Petani dan Kemandirian Desa, Jurnal Dinamika Pedesaan dan Kawasan, Volume 4, Nomor 4. 